\title{
ESTRATÉGIAS ESPACIAIS - COMO ORDENAR O TERRITÓRIO
}

\author{
JORGE GASPAR $^{1}$
}

Passado um quarto de século de dúvidas e de ensaios alternativos, a necessidade do ordenamento do território voltou a estar na ordem do dia, embora com uma ou outra inovação, não só no plano da terminologia, como na arquitectura institucional.

A inscrição prioritária nas agendas dos políticos, dos técnicos e dos estudiosos do ordenamento do território, traduz-se também numa prática da interdisciplinaridade ou mesmo da transdisciplinaridade, não necessariamente explicitada, mas naturalmente assumida. Aqui confluem não só diferentes domínios sectoriais, do ambiente à reconversão industrial, com distintas escalas espaciais: da intervenção sobre o território comunal, às tentativas de grandes esquemas de ordenamento do espaço da União Europeia.

Por outro lado, tem-se incrementado a interpenetração entre a teoria e a prática, entre o trabalho dito académico ou científico e os projectos de intervenção política ou de políticas.

É mais ou menos balizado por estas linhas de um pano de fundo decerto mais complexo, que apareceu muito recentemente uma obra que se pretende didáctica e motivadora, no sentido de ajudar a compreender e a dominar o espaço ${ }^{2}$. Dirigido ao grande público, o livro é explicitamente produzido num ambiente de convergência de diferentes disciplinas e de autores com formações diversificadas, mas todos com um largo percurso nos domínios da análise e do planeamento regional e urbano.

Assim, o resultado final não aparece como um somatório de contributos pessoais e pluridisciplinares, mas como uma visão crítica e integrada de um certo número de tópicos relevantes para a definição de estratégias espaciais, urbanas ou regionais. Não se trata, nem essa é a proposta dos autores, de uma tentativa de abordagem exaustiva. Trata-se antes de uma selecta da «ciência regional». rais»:

A obra estrutura-se em quatro capítulos, que confluem numas «conclusões ge-

O primeiro capítulo é uma discussão em torno dos conceitos da análise regional, uma perspectiva histórica e pluridisciplinar, de que emerge a evidência do grande esforço desenvolvido a partir da Economia e da Geografia. Não explicitando conclusões parcelares, os autores optam apontar as preocupações mais recentes da análise espacial, na opinião de colegas de ofício que para o efeito foram consultados.

$\mathrm{O}$ segundo capítulo é dedicado à evolução urbana e aos esforços desenvolvidos para a compreender e orientar. Após colocarem o fenómeno cidade no contexto do pensamento económico, passam em revista os contributos mais significativos (e consolidados) da teoria e prática da «ciência regional» - gravitação, difusão, lugares centrais; da Escola sociológica de Chicago; e das novas aquisições na perspectiva da relação entre a produção da cidade e a produção flexível. As preocupações mais recentes são sinteticamente abordadas segundo «chapéus»

1 Professor Catedrático da Faculdade de Letras de Lisboa, Investigador do Centro de Estudos Geográficos da Universidade de Lisboa. Faculdade de Letras, Cidade Universitária, 1699 LISBOA CODEX. tel: (01) 79402 18; fax: (01) 79386 90, e-mail: ceg@ mail. telepac.pt

2 BAilly, A.; B. GuEsnier; J.H.P. PAELINK; A. SALLEZ (1995) - Stratégies Spatiales: Comprendre et maîtriser l'espace. Montpellier, Reclus, $211 \mathrm{pp}$. 
sugestivos: crise urbana, a nova imagem urbana, a modelização, e desenvolvimento local e desenvolvimento urbano durável.

$\mathrm{O}$ terceiro capítulo, intitulado $« \mathrm{O}$ ordenamento do território e a ciência regional», introduzindo-se por uma abordagem histórica, coloca logo de início a questão «Que fazer?», o que remete para uma revisão das políticas regionais nos últimos 50 anos, do Reino Unido e da França, à União Europeia. A segunda parte do capítulo é dedicada a sucessivas e «emblemáticas» políticas implementadas em França desde a das metrópoles de equilíbrio em 1965, até às recentes medidas para reanimar os espaços rurais profundos.

O quarto e último capítulo, «Política, planificação e estratégia regional», parte do espaço europeu para o francês, sempre tendo a região como módulo privilegiado de análise e de intervenção política. Analisa as ferramentas de análise e de modelisação regional até agora utilizadas, bem como os métodos de elaboração do planeamento regional, numa perspectiva centralizadora, em contraponto com o planeamento descentralizado e contratualizado, tendo como parceiros o Estado e a Região. Por outro lado, mostra-se a necessidade de ampliar a dimensão espacial, mas também a temporal (prospectiva).

Nas conclusões gerais reforça-se a ideia da função integradora da análise espacial e do papel relevante que tem um certo número de disciplinas na explicação dos mecanismos espaciais. Por outro lado, é evidente a necessidade de coerência entre os vários níveis espaciais e tecnológicos de projectos. Daí a procura de uma política global consciente dos efeitos das estratégias espaciais sobre o ordenamento do território.

A demonstrá-lo parece estar a vontade da União Europeia ao propor a preparação de um Esquema de Desenvolvimento do Espaço Europeu (EDEC), que segundo os autores poderá «fornecer as bases de uma verdadeira estratégia europeia concertada». 